\title{
Water Education for Public Servants of Developing Countries in the post COVID-19 world
}

\author{
Saebhom Kim¹, Sukkyung Sung ${ }^{1}$, Younggyun $\mathrm{Choi}^{2, \dagger}$ \\ ${ }^{1}$ UNESCO International Centre for Water Security and Sustainable Management \\ ${ }^{2}$ Chungnam National University
}

\author{
김새봄 ${ }^{1}$, 성숙경 ${ }^{1}$, 최영균 ${ }^{2 \dagger}$ \\ ${ }^{1}$ 유네스코 물 안보 국제연구교육센터 \\ 충남대학교
}

포스트 코로나 시대, 개도국 공무원 대상 물 교육

\begin{abstract}
코로나 팬데믹 이후 개도국에서는 감염 예방을 위한 손 씻기 및 위생이 더욱더 중요해지고 있으며, 지속가능한 물 공 급을 위해 물 거버넌스 및 공무원의 역할 또한 중요해지고 있다. 이를 위해, 국내외 다양한 기관에서 공무원 역량강화 를 위한 사업을 추진해왔다. 유네스코 정부간수문학프로그램(Intergovernmental Hydrological Programme, IHP) 9단계 전략(2022-2029)에서 '4차 혁명에 대비한 물 교육'이 우선순위로 포함되어 있으며, 국내에서도 3차 국제개발협력 종합 기본계획에 물과 위생 분야 ODA를 강조하고 있다. 이에 따라, $\mathrm{KOICA}$ 및 국내 다양한 물 관련 전문기관에서 개도국 대상 물 교육 사업에 참여하고 있다. 본 연구에서는 2017년 대한민국 정부와 유네스코 협정에 의해 설립된 유네스코 물 안보 국제연구교육센터의 국제교육사업 사례를 통해, 국내 물 교육 기관들이 포스트 코로나 시대에 개도국 공무원 대상 물 교육이 나아가야할 방향을 제시하였다. 우선 물 교육 콘텐츠의 중복성을 피하기 위해 기관 간 협력이 필요하 며 온라인 콘텐츠를 활용한 블렌디드 러닝이 적극적으로 활용되어야 한다. 또한 4차 산업혁명 등 스마트 물관리에 대 한 수요가 상대적으로 높아 향후 콘텐츠 발굴시 이를 충분히 고려해야 할 것으로 판단되었다.
\end{abstract}

\begin{abstract}
After the COVID-19 pandemic, hand hygiene has become more important to prevent and reduce infection. To manage and provide water to ensure safe handwashing, water governance and the role of public servants are also getting critical. Many organizations have given their priority to capacity building of public servants. In the Strategic Plan for the ninth phase of the Intergovernmental Hydrological Programme (2022-2029), 'Water education in the Fourth Industrial Revolution' is included as a priority. In Korea, ODA in the field of water and sanitation is emphasized in Korea's 3rd Mid-term Strategy for Development Cooperation (2021-2025). Also, KOICA and various water-related organizations have been organizing water education programs for developing countries. This study presents the direction for water education for public servants in developing countries in the post COVID-19 through the education program cases of the International Centre for Water Security and Sustainable Management established by the agreement between the Korean government and UNESCO in 2017. The study suggests that water-related organizations should cooperate with each other to prevent duplication of water education contents. It also suggests that blended learning should be actively utilized for the improvement of education program effectiveness. Lastly, the study emphasizes that education demand for the water technologies related to the fourth industrial revolution and smart water management is increasing, which should be considered when water-related organizations create online content or design education programs.
\end{abstract}

KEYWORDS: COVID-19, Capacity building, Invitational Training, Online Training, Public servants in developing countries, Water Education

\footnotetext{
†To whom correspondence should be addressed.

E-mail: youngchoi@cnu.ac.kr

Received: 21 October 2021, Revised: 12 November 2021,

Accepted: 13 November 2021
} 


\section{Introduction}

2020년 코로나 팬데믹 이후 전 세계적으로 코로나 감염 을 막기 위한 손 씻기와 위생시설 등이 중요해졌으며, 깨끗 한 물은 코로나 확산 방지 관련 공공정책에서 전례 없는 관 심을 받고 있다. 하지만, 아직까지도 전 세계 인구 중 30 억 명은 가정에서조차 손을 씻기 위한 기본적인 시설이 부재 한 것으로 나타났다. 이러한 상황에서 $\mathrm{UN}-w a t e r$ 에서는 지 속가능발전목표 6번인 물과 위생을 2030년까지 달성하기 위해서는 재정, 데이터와 정보, 역량강화, 혁신기술, 그리고 거버넌스가 촉진제 역할을 할 것이라고 하였다. 특히, 많은 개도국에서는 지방정부 공무원이 물과 위생 서비스 역할을 담당하고 있기 때문에, 지역사회에 안전한 물 공급을 위해 서는 공무원의 역량강화 필요성을 강조하였다. UN 시스템 내 물 분야 유일한 정부간 조직인 유네스코 정부간수문학 프로그램(Intergovernmental Hydrological Programme, IHP) 에서는 매 8 년마다 중장기 전략을 발표하고 있다. 지난 8 단 계(2014-2021)에서는 6개 우선주제로 $\boldsymbol{\Delta}$ 물 관련 재해 및 수 문학적 변화, $\boldsymbol{\Delta}$ 환경변화로 인한 지하수의 중요성, $\boldsymbol{\Delta}$ 물 부 족과 수질 평가, $\boldsymbol{\Delta}$ 미래의 물과 인간 활동, $\boldsymbol{\Delta}$ 지속가능한 생 태수문과 공학의 조화, $\boldsymbol{\Delta}$ 물 안보를 위한 교육이 선정되었 다. 이번 2021년부터 2029년까지 진행될 IHP 9단계 전략계 획은 5 개 우선순위 주제로, $\boldsymbol{\Delta}$ 과학 연구와 혁신, $\boldsymbol{\Delta} 4$ 차 산 업혁명 시대의 물 교육, $\boldsymbol{\Delta}$ 데이터와 지식 격차 해소, $\boldsymbol{\Delta}$ 글 로벌 변화에 따른 포용적 물 관리, $\boldsymbol{\Delta}$ 과학에 기반한 물 거 버넌스 등을 담고 있다. 물 교육은 2014년부터 IHP의 세부 우선 주제로 선정되어 많은 회원국 및 이해관계자들이 물 교육의 중요성을 인지하고, 관련 사업을 추진하고 있다. 국 내에서는 코로나 이후 그린 및 디지털 뉴딜 정책을 수립하 여 시행하고 있으며, 개발협력분야에도 구체적으로 반영되 었다. 3차 국제개발협력 종합기본계획(2021-2025)는 4대 전 략목표를 제시하고 있으며, 이 중 포용적 ODA와 상생하는 $\mathrm{ODA}$ 에 수자원 및 물 분야를 강조하고 있다. 자세한 내용 을 Table 1에 정리하였다.
또한, 다양한 기관들이 개도국 대상 물 교육을 진행해오 고 있다. 장기 교육과정으로는 $\mathrm{KOICA}$ 및 환경부에서 운영 한 석사과정이 있으며, 단기 교육과정으로는 한국수자원공 사, 한국환경공단, 한국농어촌공사, 국립환경인재개발원, 유 네스코 물 안보 국제연구교육센터 등 물 관련 기관에서 운 영한 $\mathrm{KOICA}$ 글로벌 연수사업과 자체 교육과정 등이 있다.

본 연구에서는 그중에서도 대한민국 정부가 국제사회의 물 문제 해결 노력에 동참함으로써 지속가능한 발전에 기 여하기 위한 목적으로 설립한 유네스코 물 안보 국제연구 교육센터(이하 '센터')를 중심으로 살펴보고자 한다. 센터는 대한민국 정부와 유네스코 간 협정에 의해 2017년 설립된 기관으로, 대한민국 최초의 자연과학분야 카테고리 2센터 ${ }^{1}$ 이다. 센터는 환경부, 외교부, 국제기구, 국제개발은행 및 유 네스코 기관 등 국내의 물 관련 다양한 기관과 협력하여 연 구, 교육, 네트워크 사업을 추진하고 있다. 2017년부터 2021 년 10 월까지 진행한 센터 교육 사업을 살펴보고, 포스트 코 로나 시대에 개도국 공무원 대상 물 교육이 나아가야할 방 향에 대해 제시하고자 한다.

\section{Materials and Methods}

\section{1. 연례보고서 및 교육과정 결과보고서}

센터에서 매년 발간하는 연례보고서를 통해 센터에서 제 작한 온라인 교육 콘텐츠 주제와 방식에 대해 정리하였다. 또한, 2017년부터 2021년까지 진행한 교육과정을 교육 기 간, 대상, 주제, 형태, 운영방법, 협력기관 등 항목으로 구분 하여 특징 및 변화를 살펴보았다.

\section{2. 교육과정 평가 관련 자료}

센터에서는 교육 효과성 파악을 위해 교육과정 중에 별 도의 교육생 모니터링을 진행하였으며, 교육생 대상으로 교 육과정 마지막 날 교육 만족도 평가와 교육 수료 최소 1 년 후 교육 활용에 대한 사후성과평가를 실시하였다.

Table 1. "Water and Sanitation" mentioned in the 3rd Mid-term Strategy for International Development Cooperation for 2021-2025

\begin{tabular}{|c|c|}
\hline 포용적 ODA & 상생하는 ODA \\
\hline 글로벌 보건위협 대응 & 녹색전환시도 \\
\hline $\begin{array}{l}\text { 기초 위생 인프라 구축 } \\
\mathrm{o} \text { 깨끗한 물 공급을 위한 상 하수도 개선 및 세수 시설 설치 등 기초 위생 인프라 } \\
\text { 구축 지원, 공중보건수칙 등 감염병 대응 인식 제고 } \\
\text { * 개도국 수자원 관리를 위한 ODA 사업 지속 추진, WASH(Water, Sanitation and } \\
\text { Hygiene, 깨끗한 물과 보건·위생 증진사업) 등 식수·위생 관리 종합 사업 확대 }\end{array}$ & $\begin{array}{l}\text { 전략적 그린 뉴딜 ODA 추진 } \\
\text { 으래터리수소, 수자원·위생, 송·배전 효율화 등 우리의 우 } \\
\text { 수한 기술 분야를 개도국 수요가 많은 분야와 연계한 융 } \\
\text { 복합 ODA 지원 }\end{array}$ \\
\hline
\end{tabular}

1)유네스코 회원국과 유네스코 본부가 체결하는 국제협정에 근거하여 설립되며, 교육, 과학, 문화 등 전문 영역에서 활동하는 국제협력 기관임. 


\section{1 교육생 모니터링}

교육생 모니터링은 교육과정 운영 시에 교육 운영자와 참 가 전문가가 Table 2에 나타난 항목 중심으로 진행하였으 며, 매 교육과정 후 특이사항에 대해 정리하였다. 본 연구 에서는 2020년을 기점으로 교육 대상 및 선발방법 변화에 따른 교육생 특이사항에 대해 분석하였다.

Table 2. Participant monitoring contents by staff and experts

\begin{tabular}{|c|l|}
\hline 항목 & \multicolumn{1}{|c|}{ 내용 } \\
\hline 교육 참여 태도 & $\begin{array}{l}\text { 강의 참여율, 발표 및 질의응답 등 적극적 참여 } \\
\text { 태도 }\end{array}$ \\
\hline 국별보고 세미나 & $\begin{array}{l}\text { 가이드라인 반영도, 발표자료 체계성 및 가독성, } \\
\text { 발표 태도, 내용에 대한 이해도 }\end{array}$ \\
\hline 기타 협력 & 다른 문화 존중, 교육 언어 활용능력 \\
\hline
\end{tabular}

\section{2 교육 만족도 평가}

교육 만족도 평가지는 1) 전반적 만족도, 2) 강의, 3) 현 장견학, 4) 국별보고 세미나, 5) 교육환경, 6) 성취도 항목으 로 구성되어 있으며, 각 교육 특성에 따라 항목을 추가하거 나 제외하였다. 국별보고 세미나는 교육생이 교육 주제 관 련 자국의 현황 및 문제점을 발표하고, 한국 전문가가 좌장 으로 함께 참여하여 한국의 경험을 공유하는 등 참가국의 물문제 해결방안을 논의하는 세션이다. 평가지는 5 점 만점 리커트 척도를 활용한 정량적 평가와 인상 깊었던 내용 또 는 개선사항, 추가 요청사항 등 자유롭게 기술할 수 있는 정 성적 평가로 구성되어 있다. 교육 만족도 평가 분석 결과는 다음 교육과정 기획 시 반영하는데 활용하였으며, 주요 교 육 평가내용은 Table 3에 나타내었다. 본 연구에서는 교육

Table 3. Program evaluation contents by participants

\begin{tabular}{|c|c|l|}
\hline & 항목 & \multicolumn{1}{|c|}{ 내용 } \\
\hline 1 & $\begin{array}{c}\text { 전반적 } \\
\text { 만족도 }\end{array}$ & $\begin{array}{l}\text { 교육 준비과정, 강의, 현장견학, 교육 환경, 전반적 만 } \\
\text { 족도 }\end{array}$ \\
\hline 2 & 강의 & $\begin{array}{l}\text { 각 강의 주제 적합성 및 강사의 강의 전달력 등 } \\
\text { (주관식) 인상 깊었던 강의, 추가 필요한 강의 주제 등 }\end{array}$ \\
\hline 3 & 현장견학 & $\begin{array}{l}\text { 각 현장견학지 주제 적합성 등 } \\
\text { (주관식) 인상 깊었던 견학지, 추가 필요한 견학지 등 }\end{array}$ \\
\hline 4 & $\begin{array}{l}\text { 국별보고 } \\
\text { 세미나 }\end{array}$ & $\begin{array}{l}\text { 가이드라인 적절성, 좌장 세미나 운영 및 피드백 효 } \\
\text { (주관식) 기타 요청사항 }\end{array}$ \\
\hline 5 & 교육환경 & $\begin{array}{l}\text { 교육운영자 소통, 통역, 강의장, 식사, 숙박시설, 차량 } \\
\text { (주관식) 기타 요청사항 }\end{array}$ \\
\hline 6 & 성취도 & $\begin{array}{l}\text { 지식, 역량, 네트워크 등 업무에 도움이 되는 정도 } \\
\text { (주관식) 본국 교육 활용 방안 등 }\end{array}$ \\
\hline
\end{tabular}

만족도 평가지 주관식 내용을 바탕으로, 교육과정 개선방향 및 추가 수요조사 내용을 분석하였다.

\section{3 사후성과 평가}

센터에서는 2017년부터 2019년까지 교육에 참가한 111명 대상으로 교육 효과에 대한 객관적 평가 및 후속사업 발굴 을 위해 온라인 사후성과평가를 2020년에 실시하였다. 사 후성과 평가지는 $\mathrm{KOICA}$ 에서 글로벌 연수사업 참가 연수생 대상으로 진행하고 있는 사후성과 평가 설문지 양식을 간 소화하여, 현업적용도, 성과달성 저해요인, 추가 필요한 후 속사업, 온라인 교육 관심주제로 구성하였다. 총 33명이 응 답을 하였으며, 주요 현업적용도 사례와 온라인 교육 관심 주제를 중심으로 분석하였다.

\section{Results and Discussion}

\section{1. 온라인 교육 콘텐츠}

최근 코로나의 영향으로 국가 간 교류가 어려운 상황에 서 온라인 교육을 확대하기 위해, 국내 전문가 및 전문기관 과 협력하여 온라인 강의 동영상과 디지털 현장학습 콘텐 츠를 제작하였다. 콘텐츠 주제는 Table 4에 제시하였다.

Table 4. Online education contents' themes

\begin{tabular}{|l|l|}
\hline \multicolumn{1}{|c|}{ 온라인 강의 영상 } & \multicolumn{1}{|c|}{ 디지털 현장학습 영상 } \\
\hline - 지하수 & - 지하수 \\
- 자연기반해법 & - 수문조사 \\
- 도시물순환 & - 자연기반해법 \\
- 스마트물관리 & \\
- 누수관리 & \\
- 정수처리기술 \\
- 강우레이더를 이용한 홍수예보 \\
- 소하천 홍수예보 \\
- 가뭄 모니터링 및 예측
\end{tabular}

Table 4에 제시한 주제는 유네스코 8단계 및 9단계 전략 계획, 세계물개발보고서(World Water Development Report, WWDR) 및 교육생 수요를 고려하여 선정되었다. WWDR 보고서는 가장 핵심적인 UN 물 관련 보고서로 UN-water를 대신에 매년 유네스코가 발간하고 있으며, 최근 5년간 주제 는 2017년 하수재이용, 2018년 자연기반해법, 2019년 누구 도 소외받지 않는 사회, 2020년 기후변화와 물, 2021년 물 의 가치였다. 온라인 강의는 각 주제에 대한 개요 영상으로 30 분 강의 2 개로 구성되어 있으며, 센터 이러닝 플랫폼에 탑 재되어있다. 강의 영상은 온라인 교육과정 운영 시 활용하 거나 대면교육 시 교육과정 참가 전 사전자료로 활용된다. 


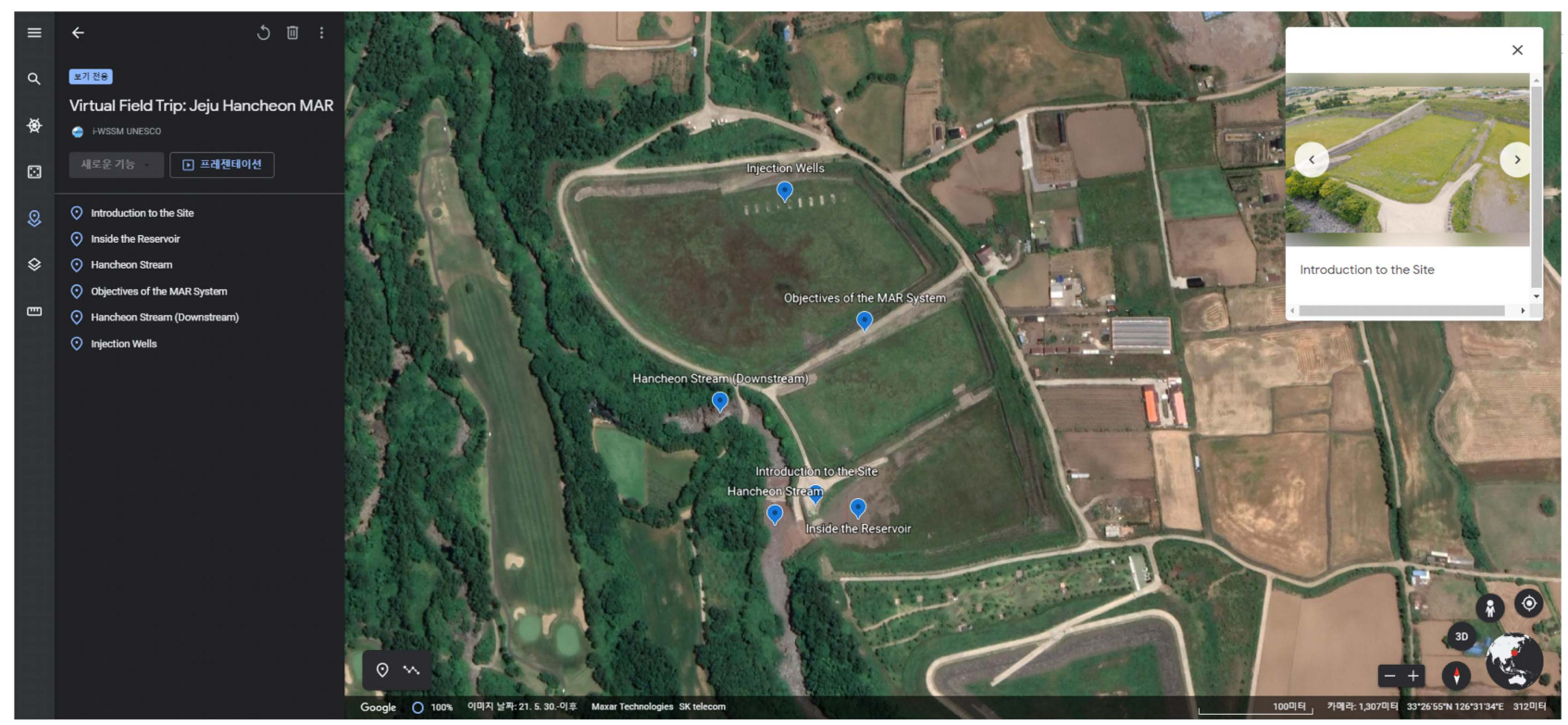

Figure 1. Virtual Field Trips (Hancheon Managed Aquifer Recharge reservoir in Jeju)

디지털 현장학습 콘텐츠는 유네스코 자카르타 사무소가 추진 중인 아시아-태평양 지역 대상 가상현장견학(Virtual Field Trips) 프로젝트 일환으로 제작되었으며, 구글 어스 (Google Earth)에 동영상을 탑재하여 위성지도 기반으로 현 장에 대해 자가학습을 하는 방식이다. Figure $1^{2}$ 과 같이 구 글 어스에 접속하면 왼쪽에는 현장 내에서 중요 장소 목록 을 확인할 수 있고, 지점을 클릭하면 관련 장소 위치로 지 도가 이동되며, 오른쪽 상단에는 시설에 대한 동영상 및 PPT 자료 등도 함께 볼 수 있다. 센터에서는 2021년 지하 수를 주제로 3 개 지역 대상으로 콘텐츠를 제작하였으며, 현 재 수문조사 및 자연기반해법(Nature-based Solutions, NBS) 주제로 제작 중이다. 디지털 현장학습 콘텐츠는 온라인 교 육 시에도 활용될 수 있지만, 대면 교육 시에도 현장방문이 어렵거나, 현장방문이 가능할 때에도 방문 전 현장에 대한 이해를 높이기 위한 목적으로도 사용될 예정이다.

국제적으로 많은 기관들이 양질의 온라인 교육 콘텐츠를 제작하고 있다. Mooc, 코세라(Coursera), World Bank Opening Learning Campus, UNESCO IHE 등에서 양질의 물 분야 온 라인 강의 영상을 무료로 수강할 수 있다. 국내에서는 한국 수자원공사 인재개발원에서 2020년 국제교육을 위한 동영 상 강의 10 편을 제작하여 홈페이지에 공개하였다. 10 개 주 제는 통합수자원관리, 기후변화, 정수처리, 수질관리, 지하 수관리, 신재생에너지, 스마트 물관리, 수문조사, 누수관리,

\footnotetext{
${ }^{2}$ https://earth.google.com/earth/d/1ZZyJ-Mq4vrsIGgyu20XIclce0JDRWoNd?usp=sharing
}

수질분석이며, 대부분은 센터 동영상 강의와 중복이 된다. 따라서 국내기관에서 물 분야 강의 동영상을 제작 시에는 사전에 기존에 공개되어 있는 온라인 동영상과 중복이 되 는지 확인할 필요가 있다. 계획한 콘텐츠가 타 기관에서 이 미 제작된 내용이라면 출처를 밝히고 활용한다면 콘텐츠 제 작에 소요되는 예산과 비용을 절감할 수 있을 것이다. 다양 한 온라인 콘텐츠가 있는 상황에서는 교육 주제에 맞는 양 질의 온라인 콘텐츠를 발굴하고, 교육생의 참여를 이끌어 낼 수 있도록 자료를 효과적으로 활용하는 전문가의 역량 강 화가 더 중요해질 것으로 판단된다.

디지털 현장학습 동영상은 한국 시설을 기반으로 하고 있 으며, 또한 국내에서도 각 시설마다 담당기관이 있기 때문 에 콘텐트가 중복될 확률은 거의 없을 것으로 예상된다. 유 네스코 자카르타 사무소가 아시아 태평양 대상 물 관련 현 장학습 플랫폼을 제작하는 것처럼, 국내에서도 물 시설을 주 제별로 살펴볼 수 있는 하나의 플랫폼을 만들어 각 물 교 육 기관들이 운영하는 시설에 대해 동영상을 제작하여 탑 재하고, 자유롭게 콘텐츠를 공유할 수 있는 체계가 마련된 다면 물 교육의 효과성을 제고할 수 있을 것으로 예상된다.

\section{2. 교육과정}

센터는 한국의 물 관리 우수사례 및 정책, 기술-인프라 공 유 및 협력 네트워크를 구축을 목적으로, 2017년부터 2021 년 10 월까지 총 22 개 교육과정을 운영하였다. 교육과정은 형태, 기간, 대상, 주제, 협력기관으로 나누어 Table 5에 나 타내었다. 대부분 초청연수 형태로 진행되었으며, 현지워크 
숍의 경우 2019년 동티모르 및 태국에서 2회 진행하였다. 교 육기간은 초청연수의 경우 5 10일, 현지워크숍의 경우 2 3 일 정도 이며, 주로 개도국 공무원 및 대학원생이 교육에 참 여하였다. 교육은 대부분 강의, 현장견학, 국별보고 세미나, 최종세미나 등으로 구성되었으며, 교육생 직급에 따라 구성 에 일부 차이를 두었다. 고위급의 경우, 현장견학, 세미나, 관 계자 미팅을 위주로 진행하였으며, 실무급의 경우, 강의, 현 장견학, 실습을 위주로 진행하였다. 2021년 10월 기준, 59 개국 410 명이 교육을 이수하였으며, 교육생 국적을 대륙별 로 살펴보면 아시아가 $72 \%$, 중남미가 $15 \%$, 아프리카는 $13 \%$ 였다. 주로 다국가 대상으로 교육과정을 진행하였으며, 단일 국 교육은 네팔, 동티모르, 인도네시아 대상으로 3건 진행되
었다.

연도별로 교육의 형태, 대상, 선발방안, 주제, 협력기관 등 은 정리하여 Table 6에 나타내었다. 센터 설립 초기에는 초 청교육과정 위주로 운영하였으며, 2019년부터는 현지워크 숍을 확대하려고 하였으나, 2020년 코로나 상황으로 초청 연수 및 현지워크솝이 불가해짐에 따라 국내 유학중인 개 도국 학생 대상으로 대면교육을 진행하였다. 교육 대상의 경 우, 2019년까지는 개도국 공무원 또는 전문가가 교육에 참 여하였다. 대부분 수자원부, 공공사업부, 환경부 등 물 관련 부처 소속 기술 분야 공무원이었으나, 일부 외교부에서 참 석한 경우도 있었다. 교육생 선발은 교육계획서와 추천요청 서를 개도국에 보내면, 개도국 정부에서 교육생을 선발하는

Table 5. Education program list (2017 Oct 2021)

\begin{tabular}{|c|c|c|c|c|c|c|c|c|c|c|}
\hline & & 과정명 & 형태 & 기간 & 대상 & 지역 & $\begin{array}{c}\text { 국가 } \\
\text { 수 }\end{array}$ & $\begin{array}{l}\text { 연수 } \\
\text { 생수 }\end{array}$ & 교육주제 & $\begin{array}{l}\text { 협력 } \\
\text { 기관 }\end{array}$ \\
\hline \multirow{3}{*}{2017} & 1 & $\begin{array}{c}1 \text { 차 IDB 및 중남미 공무원 } \\
\text { 대상 한국 수자원 지식경험 } \\
\text { 공유프로그램 }\end{array}$ & 초청 & 7일 & $\begin{array}{l}\text { 공무원 } \\
\text { (고위급) }\end{array}$ & 중남미 & 5 & 11 & $\begin{array}{l}\text { • 기후변화 } \\
\text { • 스마트물관리 }\end{array}$ & $\begin{array}{l}\text { - 국토부 } \\
\text { - IDB }\end{array}$ \\
\hline & 2 & $\begin{array}{c}1 \text { 차 아시아 물안보 전문가 } \\
\text { 역량 강화 과정 }\end{array}$ & 초청 & 10 일 & $\begin{array}{l}\text { 공무원 및 } \\
\text { 전문가 }\end{array}$ & 아시아 & 9 & 9 & $\begin{array}{l}\text { - 수자원 } \\
\text { - 상하수도 }\end{array}$ & - K-water \\
\hline & 3 & $\begin{array}{c}1 \text { 차 중앙아시아 스마트 물관 } \\
\text { 리 전문가 초청연수 }\end{array}$ & 초청 & 7일 & $\begin{array}{l}\text { 공무원 및 } \\
\text { 전문가 }\end{array}$ & 중앙아 & 3 & 8 & $\begin{array}{l}\text { - 수자원 } \\
\text { - 상하수도 }\end{array}$ & $\begin{array}{l}\text { - 한-중앙아협력포럼사무국 } \\
\text { - K-water }\end{array}$ \\
\hline \multirow{6}{*}{2018} & 4 & $\begin{array}{c}2 \text { 차 IDB 및 중남미 공무원 } \\
\text { 대상 한국 수자원 지식경험 } \\
\text { 공유프로그램 }\end{array}$ & 초청 & 7일 & 공무원 & 중남미 & 7 & 13 & $\begin{array}{l}\text { - 수자원 } \\
\text { - 환경 } \\
\text { - 민관협력 }\end{array}$ & $\begin{array}{l}\text { - 국토부 } \\
\text { - IDB }\end{array}$ \\
\hline & 5 & \begin{tabular}{|c} 
글로벌 스마트 물관리 기술 \\
교류 워크숍
\end{tabular} & 초청 & 7일 & $\begin{array}{l}\text { 공무원 및 } \\
\text { 대학원생 }\end{array}$ & $\begin{array}{l}\text { 아시아, } \\
\text { 아프리카 }\end{array}$ & 8 & 23 & $\begin{array}{l}\text { - 수자원 모델링 } \\
\text { - 갈등기반해법 }\end{array}$ & $\begin{array}{l}\text { - USACE } \\
\text { - K-water }\end{array}$ \\
\hline & 6 & $\begin{array}{c}\text { 2차 아시아 물안보 전문가 } \\
\text { 역량 강화 과정 }\end{array}$ & 초청 & 11일 & 공무원 & 아시아 & 6 & 10 & $\begin{array}{l}\text { - 상수도 } \\
\text { - 유수율제고 }\end{array}$ & - K-water \\
\hline & 7 & $\begin{array}{l}\text { 2차 중앙아시아 스마트 } \\
\text { 물관리 전문가 초청연수 }\end{array}$ & 초청 & 7일 & 공무원 & 중앙아 & 4 & 12 & $\begin{array}{l}\text { - 상수도 } \\
\text { - 수자원 } \\
\text { - 농업용수 } \\
\end{array}$ & - 한-중앙아협력포럼사무국 \\
\hline & 8 & $\begin{array}{c}\text { 세계은행 전문가 지식교류 } \\
\text { 프로그램 }\end{array}$ & 초청 & 7일 & $\begin{array}{l}\text { 세계은행 } \\
\text { 실무자 }\end{array}$ & 중남미 & 5 & 10 & $\begin{array}{l}\text { - 수자원 } \\
\text { - 환경 }\end{array}$ & - 세계은행 \\
\hline & 9 & $\begin{array}{c}\text { Smart Water Grid 운영자 } \\
\text { 양성 프로그램 }\end{array}$ & 초청 & 11일 & 공무원 & 네팔 & 1 & 10 & $\begin{array}{l}\text { - 스마트워터 그리드 } \\
\text { - 수자원 } \\
\text { - 상하수도 }\end{array}$ & - 인천대 \\
\hline \multirow{5}{*}{2019} & 10 & $\begin{array}{c}\begin{array}{c}3 \text { 차 IDB 및 중남미 공무원 } \\
\text { 대상 한국 수자원 지식경험 } \\
\text { 공유프로그램 }\end{array} \\
\end{array}$ & 초청 & 7일 & $\begin{array}{l}\text { 공무원 및 } \\
\text { 전문가 }\end{array}$ & 중남미 & 3 & 13 & $\begin{array}{l}\text { - 수자원 } \\
\text { - 스마트시티 }\end{array}$ & $\begin{array}{l}\text { - 국토부 } \\
\text { - 환경부 } \\
\text { - IDB }\end{array}$ \\
\hline & 11 & $\begin{array}{c}3 \text { 차 중앙아시아 스마트 물관 } \\
\text { 리 전문가 초청연수 }\end{array}$ & 초청 & 7일 & 공무원 & 중앙아 & 5 & 9 & - 상하수도 & - 한-중앙아협력포럼사무국 \\
\hline & 12 & $\begin{array}{c}2019 \text { 동티모르 지하수 관리 } \\
\text { 역량강화 워크숍 }\end{array}$ & 현지워크숍 & 3일 & $\begin{array}{l}\text { 공무원 및 } \\
\text { 전문가 }\end{array}$ & 태평양 & 1 & 43 & - 지하수 & - 유네스코 자카르타 사무소 \\
\hline & 13 & $\begin{array}{c}\text { 3차 아시아 물안보 전문가 } \\
\text { 역량 강화 과정 }\end{array}$ & 초청 & 8일 & 공무원 & 아시아 & 6 & 10 & - 지하수 & - 자체 \\
\hline & 14 & $\begin{array}{c}\text { 유네스코 WWAP 공동 물과 } \\
\text { 젠더 워크숍 }\end{array}$ & 현지워크숍 & 2일 & $\begin{array}{l}\text { 공무원 및 } \\
\text { 전문가 }\end{array}$ & $\begin{array}{l}\text { 아시아 } \\
\text { 태평양 }\end{array}$ & 7 & 12 & - 물과 젠더 & - UNESCO WWAP \\
\hline
\end{tabular}


Table 5. (Continued).

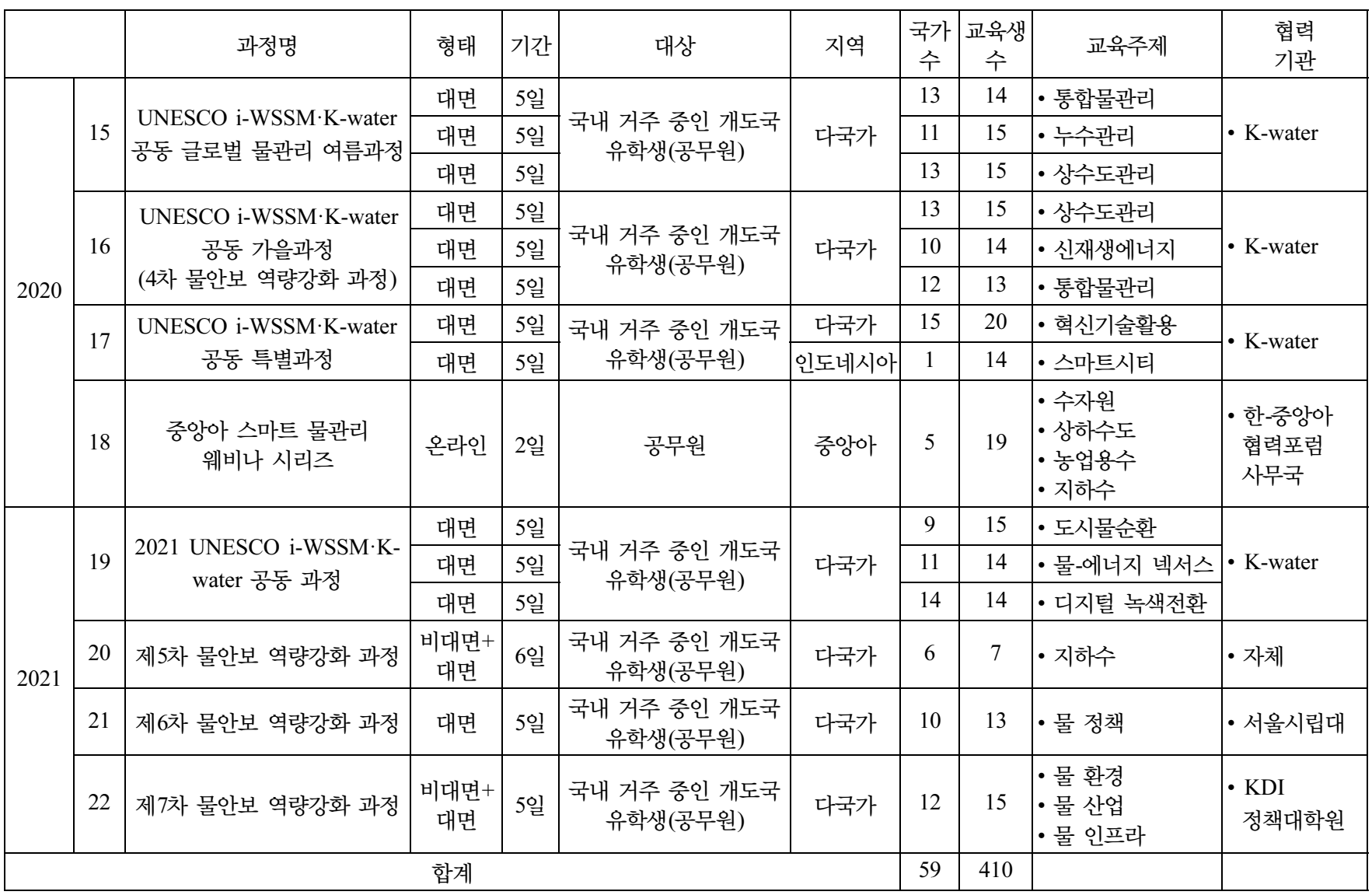

Table 6. Education Program characteristics by year

\begin{tabular}{|c|c|c|c|c|c|}
\hline & 2017 & 2018 & 2019 & 2020 & 2021 \\
\hline 형태 & \multicolumn{2}{|c|}{ 초청교육 } & $\begin{array}{l}\text { 초청교육, } \\
\text { 현지워크숍 }\end{array}$ & $\begin{array}{l}\text { 대면교육, } \\
\text { 웨비나 교육 }\end{array}$ & $\begin{array}{c}\text { 대면교육(비대면 혼합) } \\
\text { 웨비나 교육 }\end{array}$ \\
\hline \multirow{2}{*}{ 대상 } & \multicolumn{3}{|c|}{ 공무원 및 전문가 } & \multicolumn{2}{|c|}{ 국내 거주 대학원생(일부 공무원) } \\
\hline & \multicolumn{3}{|c|}{ 아시아, 중남미 위주 } & \multicolumn{2}{|c|}{ 아프리카 확대 } \\
\hline 선발 방안 & \multicolumn{3}{|c|}{ 각 국가 기관 추천을 통한 선발 } & \multicolumn{2}{|c|}{ 지원서 평가를 통한 선발 } \\
\hline 추가된 주제 & 수자원 & $\begin{array}{c}\text { 상하수도 } \\
\text { 환경 } \\
\text { 농업용수 }\end{array}$ & $\begin{array}{c}\text { 지하수 } \\
\text { 물과 젠더 }\end{array}$ & 스마트 시티, 신재 & 신기술, 그린뉴딜, NBS \\
\hline
\end{tabular}

방식으로 별도 평가절차는 부재하였다. 2020년에는 한국에 거주하고 있는 대학원생 대상으로 교육과정을 기획하면서 , 교육과정을 홍보하여 학생을 모집하고 평가하여 선발하는 방식으로 변경하였다. 선발 시 자격요건은 국내 거주자 중 물 분야에 관심 있는 개도국 유학생 및 전문가로 하였으며 , 이를 통해 아프리카 교육생으로도 확대할 수 있게 된 계 기가 되었다.

교육주제는 2017년까지는 센터 주무부처가 국토교통부였 으므로, 수자원 위주였으나, 2018년 물관리 일원화가 되면
서 환경부가 주무부처로 변경됨에 따라 상하수도, 환경 분 야로 교육 주제도 확대되었다. 그 외에도 개도국 수요가 많 은 지하수 및 농업용수도 다루었으며, 2018년 세계물개발 보고서 주제인 자연기반해법과 유네스코 우선전략인 젠더 를 고려한 물과 젠더 주제도 교육에 포함하여 국제 아젠다 를 확산하는데 기여하였다. 또한, 2020년부터 스마트시티, 신재생에너지, 그린뉴딜, 디지털 뉴딜 등 한국의 물 아젠다 현안 중심으로 교육과정을 기획하여 운영하였다. 


\section{3. 교육과정 평가 설문내용 분석}

\section{1 교육생 모니터링}

교육생 모니터링 결과는 2020년 기준으로 교육생 대상 변 화에 따라 차이가 나타났다. 2020년 이전 개도국 공무원 대 상 초청교육 시에는 교육과정 진행 언어 소통 능력이 떨어 지거나, 교육과정에 참여 태도가 좋지 않거나, 국별보고 자 료 등이 충실하지 않는 등 부적합한 교육생이 종종 참여하 였다. 하지만, 2020년 이후 교육과정에 참여한 국내 거주 대 학원생의 경우, 대부분 교육 참여도도 높았으며, 강의 및 현 장견학 시 질의응답도 적극적으로 하였으며, 질문의 수준도 높았다. 한국에 이미 거주하고 있으므로 한국에 대한 사전 이해도가 있고, 한국 대학교 석사과정 입학 시 한번 검증을 받았으며, 무엇보다 경쟁을 통한 선발방법이 교육생을 선발 하는데 영향을 주었을 것으로 판단된다. 향후, 개도국 대상 초청연수 기관이 교육생 태도(교육에 대한 의지, 적극성, 집 중도 등) 및 자격(언어능력, 전문성 등) 등을 사전 검증하기 위한 체계적인 평가 절차를 거친다면, 우수한 교육생을 선 발하여 교육과정 효과성을 제고하는데 도움이 될 것으로 판 단된다.

\section{2 교육 만족도 평가}

교육 만족도 평가지에서 언급빈도가 높았던 주관식 내용 중 '교육과정에서 인상 깊었던 내용'은 Table 7에 정리하였 다. 인상 깊었던 내용은 크게 교육구성, 강의 및 강사, 현장 견학으로 압축되었다. 교육을 구성할 때 동일한 주제에 대 해 오전에는 강의, 오후에는 현장견학을 배치하여 강의와 현
장견학이 연계될 수 있도록 하였다. 특히, 한명의 강사가 관 련 현장견학지까지 동행하여 설명해줄 때 교육 만족도 가 장 높은 것을 확인하였다. 또한, 지원서 내 교육생 관심분 야, 참가 동기, 연구 또는 본업과 연계 방안 등을 작성하도 록 하여 교육과정 기획 시에 반영하였으며, 참여 전문가들 에게도 전달하여 전문가가 교육생 수요를 바탕으로 강의 내 용 및 수준을 조정하는 등 맞춤형 교육을 진행할 수 있도 록 안내한 것이 도움이 되었던 것으로 판단된다. 현장견학 지의 경우 교육과정 주제에 따라 상이하지만, 주로 통합물 관리센터, 정수처리장의 원격통합관제시스템 등 자동화 시 스템 및 실시간 데이터 관리 기술에 대한 관심을 보였으며, 기후변화 대응 및 도시화가 점점 이슈가 되면서, 저영향개 발기법(Low-impact Development, LID)시설, 인공습지, 인공 함양 저수지 등에 대한 반응도 좋았던 것으로 확인되었다. 교육 만족도 평가지에서 언급빈도가 높았던 주관식 내용 중 교육과정 제안사항 및 개선사항은 Table 8에 정리하였다. 개선사항으로는 교육기간이 다소 짧다는 의견과 강의보다 는 현장 및 현장견학을 선호한다는 응답이 자주 확인되었 다. 교육생이 한국에 오기 전 온라인 강의 동영상을 제공하 여 사전에 수강할 수 있도록 하는 블렌디드 러닝 형태 교 육을 진행한다면 짧은 교육기간도 보완할 수 있고 강의 대 신 실습과 현장견학 등 다양한 교육을 구성할 수 있을 것 으로 판단된다. 강의 내용이 중복된다는 의견도 다수 확인 되었다. 강의의 중복성을 방지하기 위해서는 사전에 강의 목 차 등을 강사들에게 공유하여 내용을 파악하거나, 사전 강 사 워크숍을 개최하는 것도 하나의 방법이 될 수 있을 것 이다. 현장견학의 경우, 대부분 참가자가 공무원이므로, 현

Table 7. Positive responses of the program evaluation survey

\begin{tabular}{|c|c|l|}
\hline & 항목 & \multicolumn{1}{c|}{ 인상 깊었던 내용 } \\
\hline 1 & 교육구성 & 현장견학이 강의 내용을 보완해주는 형태로, 강의와 현장견학 간 유기적인 연계가 좋았음. \\
\hline 2 & 강사, 강의 & 본국의 물 이슈를 강사가 파악하고 한국의 경험을 안내해주어서 비교할 수 있어 도움이 되었음. \\
\hline 3 & 현장견학 & $\begin{array}{l}\text { 통합물관리센터, 정수처리장 원격통합관제시스템, 강우레이더, 인공습지, 지하수 인공함양지 등이 인상깊었으며 자국에 } \\
\text { 돕할 수 있을 것임. }\end{array}$ \\
\hline
\end{tabular}

Table 8. Recommendation and suggestions of the program evaluation survey

\begin{tabular}{|c|c|l|}
\hline & 항목 & \multicolumn{1}{|c|}{ 제안사항 } \\
\hline 1 & 교육 기간 & 교육과정이 좀 더 길면 좋겠음. \\
\hline 2 & 교육 구성 & 강의보다는 실습 및 현장견학을 선호함. \\
\hline 3 & 강의 & $\begin{array}{l}\text { 중복되는 강의 내용 조정이 필요함. } \\
\text { 한국의 물 분야 국제협력, 개도국 참여할 수 있는 한국의 물 프로젝트 등에 대한 강의가 추가되면 좋겠음. }\end{array}$ \\
\hline 4 & 현장견학 & 사업개요(추진 배경, 이해관계자 관리, 추진절차, 현장관리방법, 유지보수, 예산 등)에 대한 안내가 추가되면 좋겠음. \\
\hline 5 & $\begin{array}{c}\text { 국별보고 } \\
\text { 세미나 }\end{array}$ & 참가국이 당면한 물 문제에 대해 한국의 경험뿐만 아니라 다른 국가 사례도 비교 등 공유해주기를 바람. \\
\hline
\end{tabular}


Table 9. Participants' activities to apply the knowledge and experience from the program

\begin{tabular}{|c|}
\hline 1. 교육과정에서 배운 내용의 확산 여부 및 방법(확산하였음 86\%) \\
\hline $\begin{array}{l}\text { · (칠레, 카자흐스탄) 실시간 통합물관리 시스템 중요성 공유 } \\
\text { · (몽골) HEC-RAS 2D모델 적용한 연구결과 국제학회지에 등재 } \\
\text { · (카자흐스탄) 댐, 저수지에서의 수질 모니터링 } \\
\text { · (네팔) 교육내용 네팔 엔지니어협회 글 기고 } \\
\text { · (도미니카) 교육내용(사진, 교육자료)을 학부생(환경공학) 교육에 활용 }\end{array}$ \\
\hline 2. 교육과정의 경험을 바탕으로 소속 조직의 역량강화 기여 여부 및 방법(강화하였음 $86 \%$ ) \\
\hline $\begin{array}{l}\cdot \text { (에티오피아) National Flood Early Action Protocol } 2020 \text { 수립 } \\
\cdot \text { (DR 콩고) 통합수자원모니터링 및 정보 네트워크 계획 수립 중 } \\
\cdot \text { (네팔) 상수도 및 지하수분야 실무자 대상 가이드라인 및 매뉴얼 수립(유지관리/운영/모니터링 등) } \\
\cdot \text { (방글라데시) 자동물미터기수집기 설치 } \\
\cdot \text { (카자흐스탄) K-water 자동화시스템 도입 검토 중 } \\
\cdot \text { (태국, 몽골) 계획수립에 HEC-RAS 2D 모델 활용 } \\
\text { · (베트남) 물 요금 개정 관련 보고서 작성, 베트남 수리개발 전략 및 조직의 과학기술발전 계획 수립에 교육내용 활용 } \\
\cdot \text { (인도네시아) 모든 물관리시설 디지털화 도입중, 지하수 모델링 및 디지털 플랫폼 계획 수립 }\end{array}$ \\
\hline 3. 교육과정을 통한 협력관계 기반 신규 사업 또는 협력 사례(발생하였음 28\%) \\
\hline $\begin{array}{l}\text { · (방글라데시 CWASA) 상수도 사업(한국 EDCF, 방글라데시 정부) } \\
\text { · (방글라데시 DWASA) K-water 협력, 국제훈련연구센터 및 통합물운영센터 설립 (‘20.2) }\end{array}$ \\
\hline
\end{tabular}

장시설에 대한 기술적인 요소뿐만 아니라 사업의 추진 배 경, 이해관계자 갈등관리, 추진절차, 예산, 유지보수 방법 등 에 대해 관심을 보였다. 또한 국별보고 세미나 시에는 한국 경험뿐만 아니라 타 국가 사례도 비교 분석하여 공유해주 기를 바란다는 의견도 있었다.

\section{3 사후성과 평가}

사후성과 평가지는 현업적용도, 성과달성 저해요인, 후속 요청 사업 3 개 항목에 온라인 교육 관심주제 항목을 추가 하여 구성하였으며, 본 연구에서는 현업적용도와 온라인 관 심주제에 대한 내용 위주로 살펴보았다. 현업적용도는 크게 교육에서 배운 내용 확산 방법, 소속 조직에 기여 방법, 협 력 사례 발굴 가지 항목에 대해 조사를 하였으며, Table 9 에 평가결과와 주요 사례를 나타내었다.

응답자 중 $86 \%$ 가 교육과정에서 배운 내용을 발표자료 작 성에 활용, 보고서 제출, 교육자료 공유 및 개인 연구 및 논 문에 활용하였다고 응답하였으며, 또한 조직 내 기본계획, 가이드라인 매뉴얼 수립 등에 교육내용을 활용하였다고 응 답하였다. 교육과정을 통한 네트워크를 기반으로 신규 사업 및 협력 사례는 응답자 중 $28 \%$ 가 있다고 답변하였으며, 한 국과 참여 기관 간 협력 사례가 일부 확인되었다. 교육 참 가자는 대부분 개도국 공무원, 공공부문, 학계 소속으로 본 국으로 돌아가 개인 및 조직의 발전에 교육내용을 활용하 였으므로, 센터 교육사업의 목적을 달성했다고 판단된다.

센터에서는 온라인 교육 활성화를 위해 온라인 교육 관 심주제에 대해 수요조사를 사후성과 평가 때 함께 실시하
Table 10. Demands of online education needs

\begin{tabular}{|c|c|}
\hline 분야 & 내용 \\
\hline 수자원 & $\begin{array}{l}\text { - Integrated water resources management } \\
\text { - Risk Assessment of Hydraulic Structures } \\
\text { - Sedimentation Management } \\
\text { - River Management }\end{array}$ \\
\hline 지하수 & $\begin{array}{l}\text { - Groundwater Management } \\
\text { - Local groundwater-related data/information/knowledge } \\
\text { - Groundwater modeling } \\
\text { - Groundwater development } \\
\text { - Shallow and deep groundwater recharge technology } \\
\text { - Assessment of groundwater pollutant } \\
\text { - Underground dam }\end{array}$ \\
\hline 상하수도 & $\begin{array}{l}\text { - Smart water management } \\
\text { - Water quality management } \\
\text { - Water treatment and process diagnosis } \\
\text { - Wastewater treatment }\end{array}$ \\
\hline $\begin{array}{l}\text { 기후변화 } \\
\text { 대응, } \\
\text { 재해관리 }\end{array}$ & $\begin{array}{l}\text { - Disaster risk management } \\
\text { - Flood Risk Management } \\
\text { - Hydrological forecasting } \\
\text { - Water Reuse } \\
\text { - Desalination of seawater }\end{array}$ \\
\hline $\begin{array}{c}4 \text { 차 } \\
\text { 산업혁명 } \\
\text { (정보, ICT, } \\
\text { 모델링) }\end{array}$ & $\begin{array}{l}\text { - Modeling(ArcGIS, Python, R, HEC-RAS) } \\
\text { - Automation } \\
\text { - Big Data } \\
\text { - Machine Learning } \\
\text { - Information technology }\end{array}$ \\
\hline $\begin{array}{l}\text { 거버넌스, } \\
\text { 교육, } \\
\text { 정책, } \\
\text { 경제 등 }\end{array}$ & $\begin{array}{l}\text { - Organization management } \\
\text { - Environmental Education for school children } \\
\text { - Training of Trainers } \\
\text { - Water resources policy and planning } \\
\text { - Water economics }\end{array}$ \\
\hline
\end{tabular}


였으며, 수요조사 결과는 Table 10 에 나타내었다. 개도국의 온라인 교육수요는 크게 수자원, 지하수, 상하수도, 기후변 화 대응 및 재해관리, 4차 산업혁명, 물 거버넌스로 나눌 수 있었다. 국별 및 대륙별로 관심주제 경향성을 분석해보려고 하였으나, 주로 교육생 개인의 근무부서와 전공에 따라 관 심주제는 상이하였다. 특히, 정보, ICT, 모델링 등 4차 산업 혁명 관련 교육에 대한 수요가 많은 것을 확인하였으며, 이 부분에 대한 교육 준비도 필요한 것으로 판단된다.

\section{Conclusion}

센터의 현장 교육 사례를 통해 코로나 이후 더욱 더 역할 이 중요시 되고 있는 물 분야 개도국 공무원 대상 물 교육 에 대해 향후 나아가야할 방향에 대해 분석한 내용을 토대 로 아래와 같은 결론을 도출할 수 있었다.

첫째, 코로나 이후 국내외 많은 기관들이 온라인 물 교육 콘텐츠를 개발하고 있으므로, 교육 콘텐츠에 대한 중복성을 피하기 위해 국내기관 간 협력이 필요하며, 양질의 콘텐츠 를 활용하는 역량도 중요해 질 것으로 판단된다. 디지털 현 장학습 플랫폼은 각 기관이 담당 시설에 대한 교육자료 공 유할 수 있다는 점에서 개발이 된다면, 국외 온라인 콘텐츠 와도 차별화 될 수 있으며 활용성이 클 것으로 예상된다.

둘째, 교육 주제 측면에서, 스마트 물관리, 통합물관리센 터, 원격통합관제시스템 등에 대한 교육 반응이 좋았고 수 요 또한 많았다. IHP 9단계 전략계획에서도 4차 산업혁명 물 교육을 강조하고 있는 바, 한국이 강점이 있는 ICT, 빅 데이터, 센서, 드론, 로봇 등을 접목한 물 관리에 대한 교육 콘텐츠 제작 및 교육과정 수요가 점차 증대될 것으로 예상 되며, 이에 따른 준비도 필요한 것으로 판단된다.

셋째, 교육생 선발 시 추천보다는 교육생의 태도 및 역량 을 사전에 평가할 수 있는 체계를 구축하는 것이 교육의 효 과성을 높이는데 도움이 될 것으로 예상된다. 또한, 국내 수 학중인 개도국 학생 대상 교육도 코로나 이후에도 지속하
면 좋을 것으로 판단된다. 이미 한국에 대한 충분한 경험이 있으며, 학위 후 본업에 복귀했을 때 한국과 협력을 강화하 는데 기여할 수 있을 것이다. 이를 위해서는 국내 대학 및 공공기관 간 협력 확대가 필요하다.

넷째, 코로나 상황이 종료된다고 해도, 초청연수의 여러 가지 장점들을 고려했을 때 초청연수가 중단되지는 않을 것 이다. 기존에 제작한 온라인 콘텐츠를 활용하여 블렌디드 러 닝 형태로 교육을 운영한다면 현장견학 및 실습, 세미나 등 의 비중을 더 높여 좀 더 다각적인 교육과정으로 구성할 수 있을 것이다. 블렌디드 러닝 교육의 효과성을 높이기 위해 서는, 온라인 교육에 적합한 소프트웨어 활용 등 교육공학 적인 연구가 추가적으로 필요할 것으로 판단된다.

\section{References}

Hannah, D.M., Lynch, I., Mao, F. et al. (2020). Water and sanitation for all in a pandemic, Nat Sustain 3, pp. 773-775.

Korea International Cooperation Agency (KOICA). (2020). Manual for performance management of Korea's fellowship program, KOICA, pp. 70.72. [Korean Literature]

Korea Water Resources Corporation (K-water). (2020). K-water Academy, http://www.kwater.or.kr/academy/edu/eduList.do? menu_code $=0201$ (accessed Oct. 2021.)

UNESCO International Centre for Water Security and Sustainable Management, https://www.unesco-iwssm.org/board/lists? bbsNo $=0000000065$ (accessed Oct. 2021.)

United Nations Educational, Scientific and Cultural Organization (UNESCO). (2021). Engineering for Sustainable Development, https://unesdoc.unesco.org/ark:/48223/pf0000375644. locale $=$ en

UN-water. (2020). The Sustainable Development Goal 6 Global Acceleration Framework, https://www.unwater.org/publications/the-sdg-6-global-acceleration-framework/ 